\title{
Timescales of regional circulation of saline fluids in continental crystalline rock aquifers (Armorican Massif, western France)
}

\author{
A. Armandine Les Landes, L. Aquilina, P. Davy, V. Vergnaud-Ayraud, and C. Le Carlier \\ Geosciences Rennes, CNRS - UMR6118, University of Rennes 1, Bâtiment 14B, Campus Beaulieu, \\ 263 Avenue du Général Leclerc, 35042 Rennes, France
}

Correspondence to: A. Armandine Les Landes (armandine.antoine@orange.fr)

Received: 20 April 2014 - Published in Hydrol. Earth Syst. Sci. Discuss.: 23 June 2014

Revised: - - Accepted: 25 February 2015 - Published: 16 March 2015

\begin{abstract}
In recent decades, saline fluids have been sampled worldwide at great depths in continental basements. Although some of them have been attributed to marine transgressions, the mechanisms allowing their circulation are not understood. In this paper, we describe the horizontal and vertical distributions of moderately saline fluids (60 to $1400 \mathrm{mg} \mathrm{L}^{-1}$ ) sampled at depths ranging from 41 to $200 \mathrm{~m}$ in crystalline rock aquifers on the regional scale of the Armorican Massif (northwestern France). The horizontal and vertical distributions of high chloride concentrations are in good agreement with both the altitudinal and vertical limits and the succession of the three major transgressions between the Mio-Pliocene and Pleistocene ages. The mean chloride concentration for each transgression area is exponentially related to the time spanned until the present. It defines the potential laws of leaching (displacement) of marine waters by fresh meteoric waters. The results of the Armorican aquifers provide the first observed constraints for the timescales of seawater circulation in the continental crystalline basement and the subsequent leaching by fresh meteoric waters. The general trend of increasing chloride concentration with depth and the time frame for the flushing process provide useful information to develop conceptual models of the paleofunctioning of Armorican aquifers.
\end{abstract}

\section{Introduction}

In recent decades, saline fluids have been sampled at great depths $(0.5-5 \mathrm{~km})$ in continental basements (Bucher and Stober, 2010; Frape et al., 2003). In several places, these fluids have been considered as old seawater introduced into aquifers during marine transgressions (Aquilina and Dreuzy, 2011; Beaucaire et al., 1999; Bottomley et al., 1994, 1999; Douglas et al., 2000; Greene et al., 2008; Louvat et al., 1999; Négrel and Casanova, 2005). Two alternative origins related either to glacial recharge of brines due to cryogenic mechanisms (Starinsky and Katz, 2003) or to anthropogenic sources (Kelly et al., 2008; Mullaney et al., 2009; Panno et al., 2006; Perera et al., 2013) have also been proposed. These three hypotheses have led to extremely different estimates of the saline fluid residence time (Devonian or Pleistocene for the Canadian brines, for example) and thus of the paleohydrogeology of the continental aquifers. Although thorough investigations have been carried out in several places, the origin and fate of the salinity are still issues. We have almost no field observations identifying the potential mechanisms leading to marine fluid introduction and conservation in hard rock aquifers, and the influence of glacial recharge at various depths in these aquifers remains. Furthermore, the timescales of these mechanisms are unknown.

In this study, we investigated the effects of marine transgressions in the spatial (both horizontal and vertical) distribution of chloride concentrations on a regional scale. Since the transgression characteristics differ from one event to another, we expect to find higher concentrations in the areas flooded by the latter. The decrease in chloride concentrations with time potentially provides constraints for fluid circulation timescales in the basement. This concept is based on the fact that, during transgression, a large number of chlorides were introduced in flooded areas. Secondly, the chloride concentration of the submerged area decreases under the influence of dilution/leaching by meteoric waters. Thus, the decline in chloride concentration since the time of the last trans- 
gression is characteristic of the dilution/leaching efficiency. This makes it important to identify the last transgression that has flooded the considered area.

The study focuses on the Armorican basement (western France), where several authors have reported evidence of saline fluids (Ayraud et al., 2008; Pauwels et al., 2010). Three main transgressions were recorded during Mio-Pliocene to Pleistocene times, the latest being the highest. This is a particularly favorable context, since a large part of the area flooded by the oldest and highest transgression remains unaffected by later transgression events.

\section{Geological background}

The Armorican basement extends over an area of $68500 \mathrm{~km}^{2}$ in the northwestern part of France. The Armorican Massif is a crystalline basement localized between the English Channel and the Bay of Biscay. The northern part corresponds to the Cadomian orogenic belt (Chantraine et al., 2001). The central and southern zones belong to the European Variscan belt (Le Corre et al., 1991). The Armorican Massif is a basement made of Upper Proterozoic to Paleozoic formations mainly composed of low and high metamorphic rocks (schists, sandstones and gneisses, etc.), plutonic (granite) and volcanic (basalt) rocks deformed during the two orogenies (Cadomian and Variscan) (Fig. 1). These orogenies initially developed the main tectonic structures of the Armorican Massif: the North and South Armorican shear zones (NASZ and SASZ, respectively), and the Quessoy/Nort-surErdre fault (Bonnet et al., 2000) (Fig. 1). These structures were reactivated during the Mesozoic and Cenozoic periods. Tertiary and quaternary geodynamic evolutions of the Armorican Massif are related to the collision between Europe and Africa (Brault, 2002; Gros and Limasset, 1984; Ziegler, 1990). This evolution mainly consists of three major steps (Thomas, 1999): (1) from the end of the Cretaceous to the upper Eocene, the Armorican Massif is subjected to a lithospheric buckling due to the Pyrenean compression. (2) From the upper Eocene to the Oligocene, the buckling decreases and the geodynamic evolution is driven by a generalized extension. (3) From the Mio-Pliocene to the present day, the Armorican Massif is uplifted due to a lithospheric buckling in relation to the Alpine compression. This compression is still active, as observed through the Armorican Massif seismic activity (Lenôtre et al., 1999; Nicolas et al., 1990).

Local topography is controlled by rock lithologies and, on a larger scale, by tectonic faults (northern and southern shear zones - Dugué, 2007; Gumiaux et al., 2004). It is relatively moderate, with three domains of higher elevation above $200 \mathrm{~m}$ and a maximum elevation of $416 \mathrm{~m}$ in the east (Fig. 2).

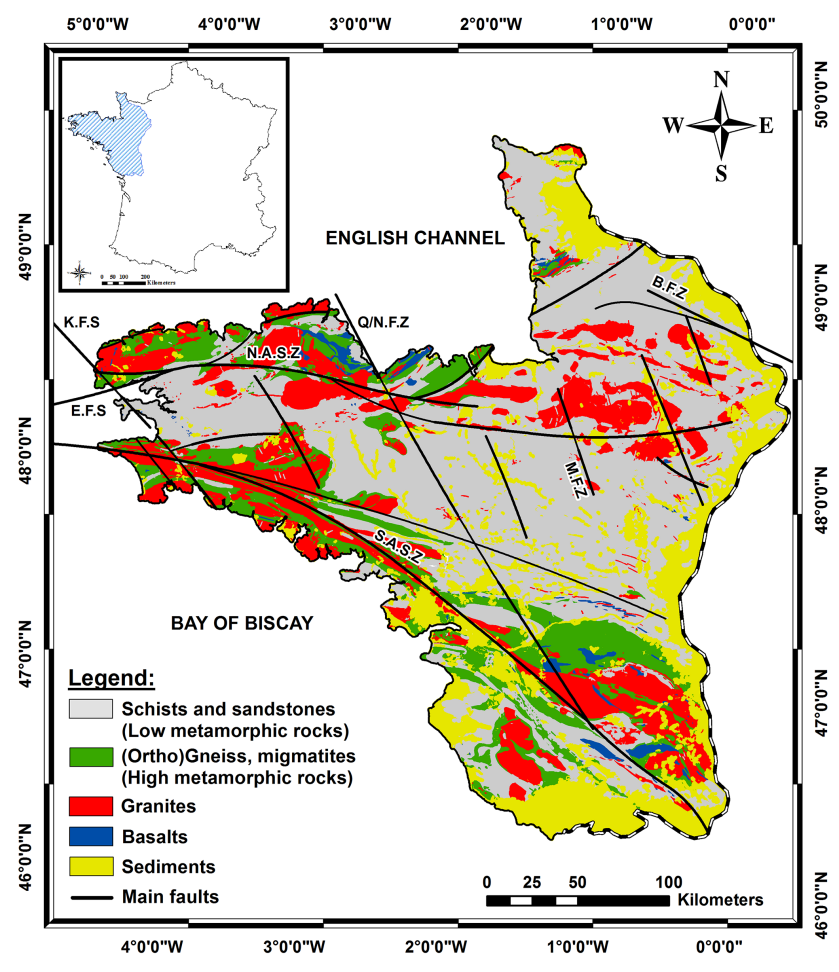

Figure 1. Simplified geological map of the main lithological units and main geological structures of the Armorican Massif. NASZ: North Armorican Shear Zone; SASZ: South Armorican Shear Zone; Q/NFZ: Quesssoy/Nort-sur-Erdre Fault Zone; MFS: Mayenne Fault System; KFS: Kerforne Fault System; and EFS: Elorne Fault System (according to Bonnet et al., 2000).

\section{Hydrogeological setting}

The main groundwater flow in crystalline rock aquifers is considered to be localized in superficial formations resulting mainly from rock weathering, and below in fracture and major geologic discontinuity networks (Larsson, 1987; Stober and Bucher, 2007; Wyns et al., 2004). The compartmentalized structure includes various reservoir scales and characteristic physical parameters (permeability, porosity, etc.) varying over several orders of magnitude (Clauser, 1992). On the scale of the Armorican Massif, a weathered layer 20 to $30 \mathrm{~m}$ thick is present in many places, and likely ubiquitously (Brault, 2002; Dewandel et al., 2006). Roques (2013) has studied the influence of fault zones for sites characterized by high groundwater yields on the scale of the Armorican Massif. On this scale, groundwater resources in the shallower part $(<20 \mathrm{~m})$ are widespread but limited in terms of productivity. Conversely, high groundwater productivities are associated with fault zones below the weathered zone. Indeed, groundwater resources at significant depth have been found in the Armorican bedrock (Le Borgne et al., 2006; Leray et al., 2013; Roques et al., 2014), and it can be considered that the fractured system constitutes a water reservoir in the conti- 


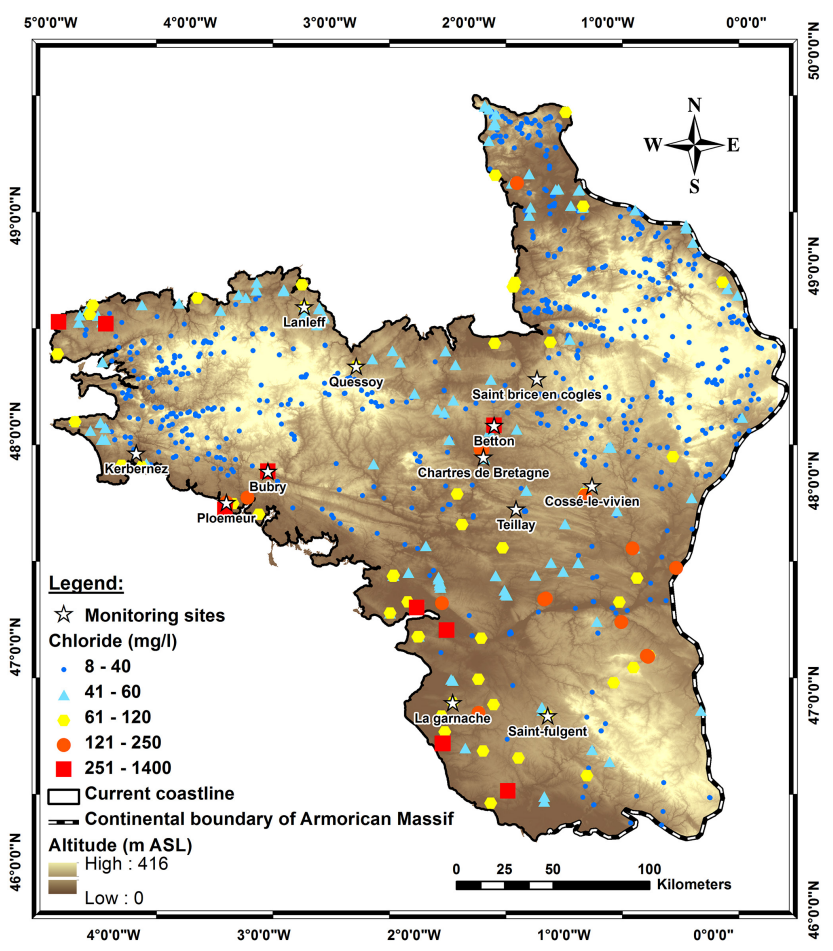

Figure 2. Map of the Armorican Massif including the distribution of chloride concentrations for the whole area (from a preprocessed chloride database) and the location of the 12 sites investigated.

nental basement. Free groundwater circulation in crystalline environments has been reported from several studies (Banks et al., 1996; Larsson, 1987). Several studies have shown that the basement is generally characterized by an interconnected fracture system at several kilometers in depth (Aquilina and Dreuzy, 2011; Edmunds and Savage, 1991; Stober et al., 2002). Hydrodynamic properties of crystalline rock aquifers of the Armorican basement have been intensively investigated at several research sites (Ploemeur and St-Brice-enCogles sites, Fig. 2) (Le Borgne et al., 2004, 2006; Dorn et al., 2012; Leray et al., 2013; Roques, 2013; Roques et al., 2014; Touchard, 1999) (Fig. 2). Moreover, previous studies in the Armorican basement have identified a compartmentalization of these crystalline rock aquifers from hydrological, geochemical, geological and geophysical data (Ayraud et al., 2008; Roques, 2013; Roques et al., 2014), and from regional-scale numerical modeling (Goderniaux et al., 2013). Geochemical studies also showed specific chemical compositions of the water in the deep fractured aquifer, potentially including saline groundwaters (Aquilina et al., 2013; Ayraud et al., 2008; Pauwels et al., 2013).

\section{Chloride database}

The quantity supplied and the quality of the main groundwater resources in the Armorican Massif are monitored through a public well network (ADES: banque nationale d'Accès aux Données sur les Eaux Souterraines, national database for groundwater resources, http://www.ades.eaufrance.fr/). For most of these wells, hydrogeological information (geographical location, altitude, depth, drilling log, borehole parameters, water inflow points, etc.) is available through a second public database of drillings (BSS: Base de données du Sous-Sol, http://infoterre.brgm.fr/). The precise location of water inflows is not described for each well, and it has been considered that the water inflow corresponds to the base of the well. This assumption is valid, taking into account the drilling goal, which is to stop the well drilling when sufficient water inflow is found.

The network of wells investigated covers the whole Armorican basement and includes more than 1800 drillings with an average depth of approximately $40 \mathrm{~m}$. Chemical records, such as chloride or nitrate concentrations, are available for each drilling. We first preprocessed the database of 1874 chloride measurements and removed wells that are potentially not representative of natural chloride concentrations. We removed wells close to a potential anthropic pollution source (industrial estate, garbage dump, mill pond, etc.), and wells with a large variability through time (large standard deviation of chloride concentration higher than $30 \%$ ). We also did not consider the wells at a distance of less than $1 \mathrm{~km}$ from the current coastline, whose concentration may be directly influenced by current saltwater intrusion. 716 of the 1874 wells have been excluded from the database, i.e., $38 \%$ of the total. The vertical distribution of the chloride concentrations for the remaining values was analyzed by intervals of $10 \mathrm{~m}$ from an altitude of $350 \mathrm{~m}$ a.s.l. (above sea level) to $-125 \mathrm{~m}$. The average chloride concentration and the 90th percentile were calculated for each $10 \mathrm{~m}$ interval.

\section{Marine transgression characteristics}

Chlorides of marine origin that are not brought by rainfall (i.e., concentrations higher than $40 \mathrm{mg} \mathrm{L}^{-1}$ ) are likely related to marine transgressions that flooded the Armorican Massif from time to time. The likely scenario is that a fairly large number of chlorides are injected during each transgression into submerged regions, and that the salt concentration decreases from the end of the transgression event due to dilution or leaching by meteoric waters. If the leaching/dilution is efficient enough, for instance if the time lag between two successive transgressions is larger than the leaching time, the system is fully reset by the last event (i.e., the amount of chloride injected during the last event is much larger than the residual of formers). The objective of this part is to characterize the last transgressions that have flooded the Armorican Massif.

According to stratigraphic record studies in the Armorican Massif and, to the eustatic sea-level fluctuations (Hardenbol et al., 1998), three main transgressions can be identi- 
fied since the Mio-Pliocene. The oldest of Messinian age has been identified in several places (Néraudeau et al., 2003; Van Vliet-Lanoe et al., 1998) and dated between 6 and $4.6 \mathrm{Myr}$ by several methods (electron spin resonance (ESR) spectroscopy on quartz, ${ }^{87} \mathrm{Sr} /{ }^{86} \mathrm{Sr}$ on shells and bones in Redonian shelly sands or Faluns) (Mercier et al., 2000; Néraudeau et al., 2002). These sediments would attest to the maximum transgression of the late Neogene in northwestern France (Néraudeau et al., 2010). This transgression corresponds to a high sea level of $+90 \mathrm{~m}$ according to Hardenbol et al. (1998). The second transgression is mostly characterized by the deposition of clays, which contain few bioclastic constituents (Morzadec-Kerfourn, 1997, 1977). The so-called Redon clay formations are dated as Pliocene: Piacenzian (Reuverian, $\sim 2.7 \pm 0.3 \mathrm{Myr}$ ) from a pollen analysis (Morzadec-Kerfourn, 1982, 1997). The corresponding sea level is around $+60 \mathrm{~m}$ according to the chart (Hardenbol et al., 1998). The last known transgression in the area is characterized by clay deposits that cover the Redon clays (Morzadec-Kerfourn, 1997). According to pollen analysis of the Lanrinou clay at Landerneau (Morzadec-Kerfourn, 1982, 1997), these sediments can be correlated with the lower Pleistocene around 1.6-2 Myr (Gelasian/Calabrian). The corresponding event coincides with the high sea-level position of $+30 \mathrm{~m}$ (Hardenbol et al., 1998).

Thus, at least three marine transgressions, with three different paleocoastlines, must be considered for the Armorican Massif: the oldest, which is also the highest, is Mio-Pliocene: Messinian $(\sim 5.3 \pm 0.8 \mathrm{Myr})$ with sea level $+90 \mathrm{~m}$ a.s.l. The second is Pliocene, Reuverian $(\sim 2.7 \pm 0.3 \mathrm{Myr})$ with sea level $+60 \mathrm{~m}$ a.s.l., and the most recent is Pleistocene, Gelasian/Calabrian $(\sim 1.8 \pm 0.2 \mathrm{Myr})$ with sea level +30 m a.s.l.

Using local studies on the large-scale relief development and the paleotopographic evolution of the Armorican basement (Bonnet et al., 1998, 2000; Brault et al., 2004; Guillocheau et al., 2003; Lague et al., 2000; Lenôtre et al., 1999; Morzadec-Kerfourn, 1997; Van Vliet-Lanoe et al., 1998), a paleotopography was reconstructed for the whole area.

Globally, the topography evolution is the result of tectonic movements, climate and eustatic variations since the MioPliocene. The modern topography is characterized by incised valleys with an incision average depth of $60-100 \mathrm{~m}$ and significant topographic variations. The onset of the current incised and dense hydrological network is probably not older than 1 Myr (Bonnet et al., 1998, 2000; Lefebvre et al., 1994). This topography contrasts with the smooth planation surface of the Mio-Pliocene (Brault et al., 2004). The development of the Pleistocene topography of the Armorican Massif is explained by vertical movements due to the N160 compression generated by the Alpine collision (Bonnet et al., 1998; Müller et al., 1992; Nicolas et al., 1990). This differential tectonic uplift has been estimated from geomorphological studies (Bonnet et al., 1998, 2000; Lague et al., 2000). Incision is measured using a digital elevation model analysis. A dis- tributed field of incised quantities is produced for each individual drainage basin (Jost, 2005). Moreover, relief induced by fluvial incision partly reflects continental movements and can be used to estimate uplift. Indeed, considering that the drainage networks adjust to sea level, the induced incision has the same magnitude in different basins. Thus, the difference in incision is used to estimate the relative amounts of differential uplift between basins. The estimation of differential uplift for each basin has been grouped by zone due to the regional organization. A differential tectonic uplift has been observed for the western part compared to the eastern part, along the Quessoy/Nort-sur-Erdre fault (Brault et al., 2004; Jost, 2005).

From this previous work, to reconstruct the paleotopography of the whole area, we first used a digital elevation model (DEM, $100 \mathrm{~m}$ resolution) given by the Institut Géographique National (IGN) to generate several surfaces providing an estimation of the Pleistocene topography prior to erosion and valley incision (Bonnet et al., 1998, 2000). Within a rectangular $20 \mathrm{~km}$ large sliding window, either the highest point or the $Q_{90}$ quantile was recorded. This process allows for the creation of a surface above the present-time topography connecting the highest points and filling the valleys. The use of the $Q_{90}$ quantile provides a smoother result than the maximum, which may be overly influenced by isolated peaks. The generated surface does not include the unknown amount of erosion of peaks and crests, and thus should be considered a minimum. Then, the uplift (Jost, 2005) was subtracted from the preprocessed topography. Lastly, the paleocoastlines were reconstructed for the three transgressions by comparing the reconstructed topography with the expected sea level derived from Hardenbol et al. (1998). The Messinian and Reuverian transgressions covered a large part of the Armorican Massif, except the highest elevations; the last Gelasian/Calabrian transgression flooded areas along the current coastline, and the lowest inland parts (Fig. 3).

\section{Results}

\subsection{Origin of chlorides}

Within the framework of this study, 12 sites (monitoring sites in Fig. 2) presenting moderately saline fluids (relative to the high chloride concentration) were subjected to further geochemical and isotopic analysis (only $\mathrm{Br}$ concentrations are presented here; see Aquilina et al., 2015). Salinities ranging from 60 to $1400 \mathrm{mg} \mathrm{L}^{-1}$ were recovered at depths ranging from 41 to $200 \mathrm{~m}$, except for the Cinergy drilling project, where water was collected at a depth below $450 \mathrm{~m}$ in a fractured schist, with a chloride concentration of $1240 \mathrm{mg} \mathrm{L}^{-1}$.

The chloride to bromide relationships are presented in Fig. 4 for the 12 sites investigated geochemically. The chloride concentration is linearly correlated with bromide along the rainfall-seawater mixing line (Fig. 4). This strongly sug- 


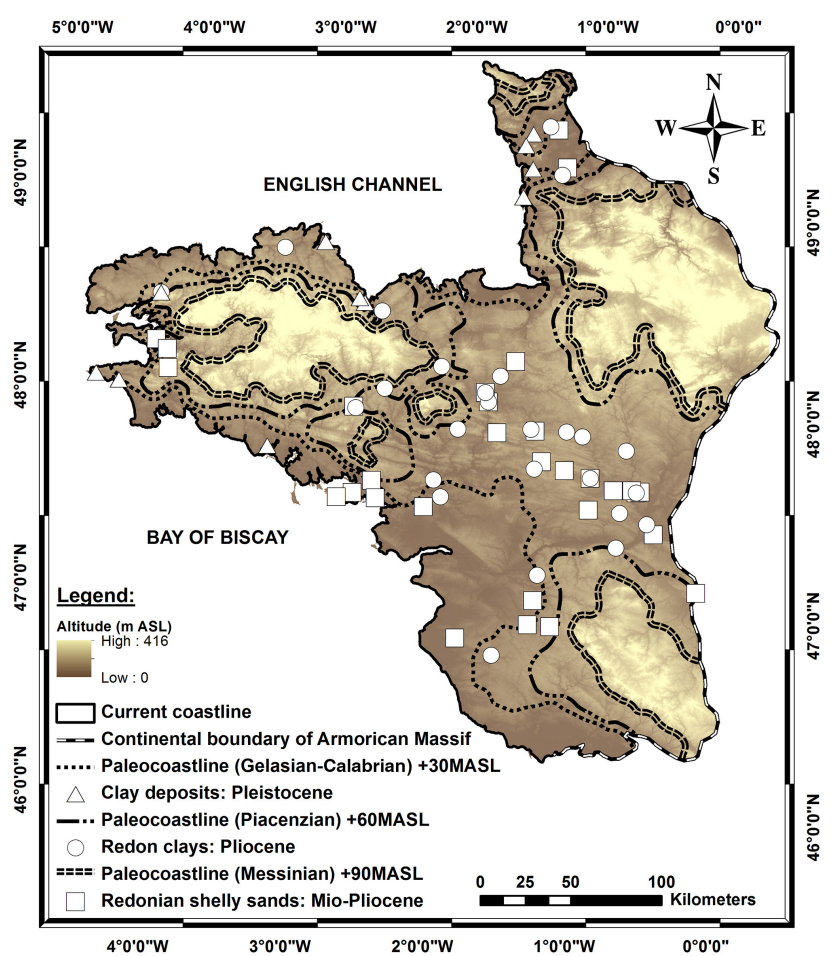

Figure 3. Localization of paleocoastlines on the current topography for past marine transgressions since the Mio-Pliocene time and characteristic sediments associated with each flooding period.

gests that the saline fluids in the Armorican basement are of marine origin and correspond to paleoseawater diluted by meteoric waters (Bottomley et al., 1994; Casanova et al., 2001; Frape et al., 1984; Fritz, 1997; Gascoyne and Kamineni, 1994; Nordstrom et al., 1989).

Chloride has three potential sources: (1) (paleo)seawater, (2) rainfall potentially concentrated by evapotranspiration processes, and (3) anthropogenic sources (agricultural fertilizers such as $\mathrm{KCl}$, pig slurry and cattle manure). If we exclude a $1 \mathrm{~km}$ band across the coastline, the meteoric waters in Brittany have a maximum mean chloride concentration of $10-18 \mathrm{mg} \mathrm{L}^{-1}$ with a relatively low variation range (Ayraud et al., 2008; Martin et al., 2004). Evapotranspiration in Brittany represents about $50-60 \%$ of the total precipitation, and cannot provide chloride concentrations in recharge water higher than $40 \mathrm{mg} \mathrm{L}^{-1}$ (Ayraud et al., 2008). Agricultural pollution may increase the concentrations to $50 \mathrm{mg} \mathrm{L}^{-1}$ in the most intensively farmed areas (Martin et al., 2004). Thus, these two processes cannot explain the very high concentrations observed. Furthermore, a negative correlation between nitrate and altitude has been observed. Above $100 \mathrm{~m}$, the nitrate concentration is almost constant, and below $100 \mathrm{~m}$, the nitrate concentration decreases with depth. This negative correlation between nitrate and altitude as well as gas groundwater dating (Ayraud et al., 2008) clearly indicates that, below this depth, the anthropogenic influence decreases. These

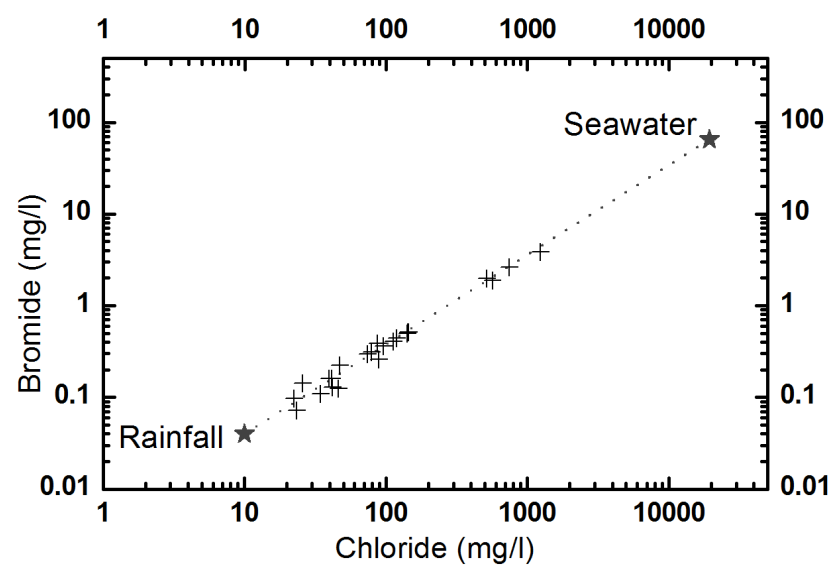

Figure 4. $\mathrm{Br}$ versus $\mathrm{Cl}$ concentrations of groundwater at the 12 sites investigated.

results underline the fact that the anthropogenic sources are more related to shallow aquifers, contrary to deep saline fluids. Many other sources of chloride exist (as evaporitic deposits of geological formation, etc.), but the relationships between chloride and bromide will be completely different for evaporated brines or evaporite leaching.

Thus, chloride concentrations are clearly out of the potential range of modern waters, even including anthropogenic sources. The correlation between bromide and chloride (Fig. 4) supports a marine origin for this groundwater (Bottomley et al., 1994; Carpenter, 1978; Freeman, 2007). The simplest mechanism that explains the high chloride concentration observed is a marine component related to the last transgressions.

\subsection{Spatial and vertical distributions of chloride}

The chloride distribution presented in Fig. 5 shows the altitudinal limits of the last three major transgressions between the Mio-Pliocene and the Pleistocene (Messinian $\sim 5.3 \mathrm{Myr}$, Piacenzian $\sim 2.7 \mathrm{Myr}$ and Gelasian-Calabrian $\sim 1.8 \mathrm{Myr}$ ). These limits correspond to 90,60 and $30 \mathrm{~m}$, respectively. This map shows relatively high chloride concentrations (60 to $1400 \mathrm{mg} \mathrm{L}^{-1}$ ) around the current coastline and in a few large domains whose current topography is clearly above sea level. Only three zones present chloride concentrations below $40 \mathrm{mg} \mathrm{L}^{-1}$. These zones correspond to the three domains of elevation higher than $200 \mathrm{~m}$ and to the area above the higher Messinian paleocoastline altitude of $+90 \mathrm{~m}$ a.s.l. Figure 6 shows the vertical distribution of chloride concentrations according to the altitude of the base of the well. Above $100 \mathrm{~m}$, the chloride concentration is almost constant, increasing only slightly with depth, with the values ranging from 10 to $40 \mathrm{mg} \mathrm{L}^{-1}$. Below $100 \mathrm{~m}$, some drastic changes in the chloride depth trends are observed. The main one is apparent at approximately $70 \mathrm{~m}$, with chloride concentrations up to $200 \mathrm{mg} \mathrm{L}^{-1}$ observed below this depth. The chloride 


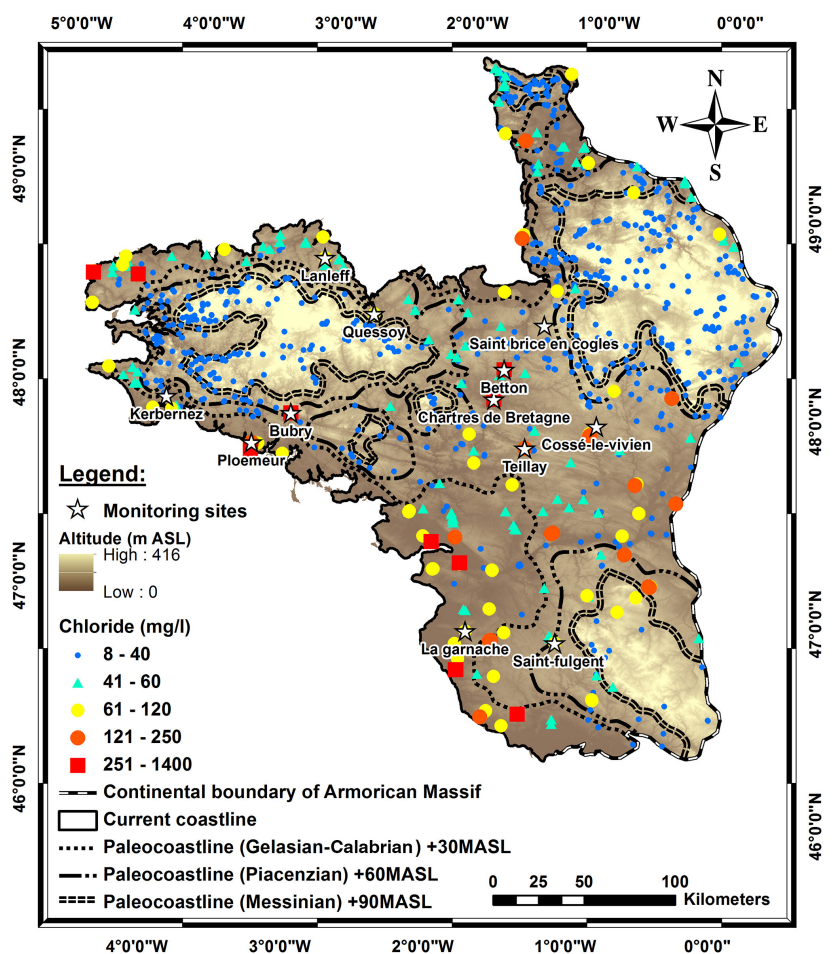

Figure 5. Distribution of paleocoastlines on the current topography for the three transgressions.

concentrations below $70 \mathrm{~m}$ increase strongly with depth (approximately $0.5 \mathrm{mg} \mathrm{L}^{-1} \mathrm{~m}^{-1}$ for the average and more than $1 \mathrm{mg} \mathrm{L}^{-1} \mathrm{~m}^{-1}$ for the 90 th percentile). This trend contrasts with the almost constant chloride concentrations in the areas not affected by past marine transgressions.

The distribution of chloride concentrations is in good agreement with the paleocoastlines (Fig. 5). The increase in chloride concentration with depth (Fig. 6) also supports this correlation. The vertical distribution of chloride concentrations likely indicates that, during each of the last transgressions, seawater was introduced by gravity-driven flow at great depth in the basement, and has only partially been flushed by meteoric waters.

\subsection{The chloride releasing rate}

The three paleocoastlines of past marine transgressions can be used to define four spatially distinct domains in the Armorican Massif: three of them correspond to places where either one of the Messinian, Reuverian and Gelasian-Calabrian transgressions is the last marine event that covered them; the fourth is the domain that was not flooded (Fig. 5). The average chloride concentration for each area has been calculated and attributed to the age of the latest marine transgression. Figure 7 shows that the average chloride concentration for each area is inversely related to the time elapsed since the last corresponding marine transgression.

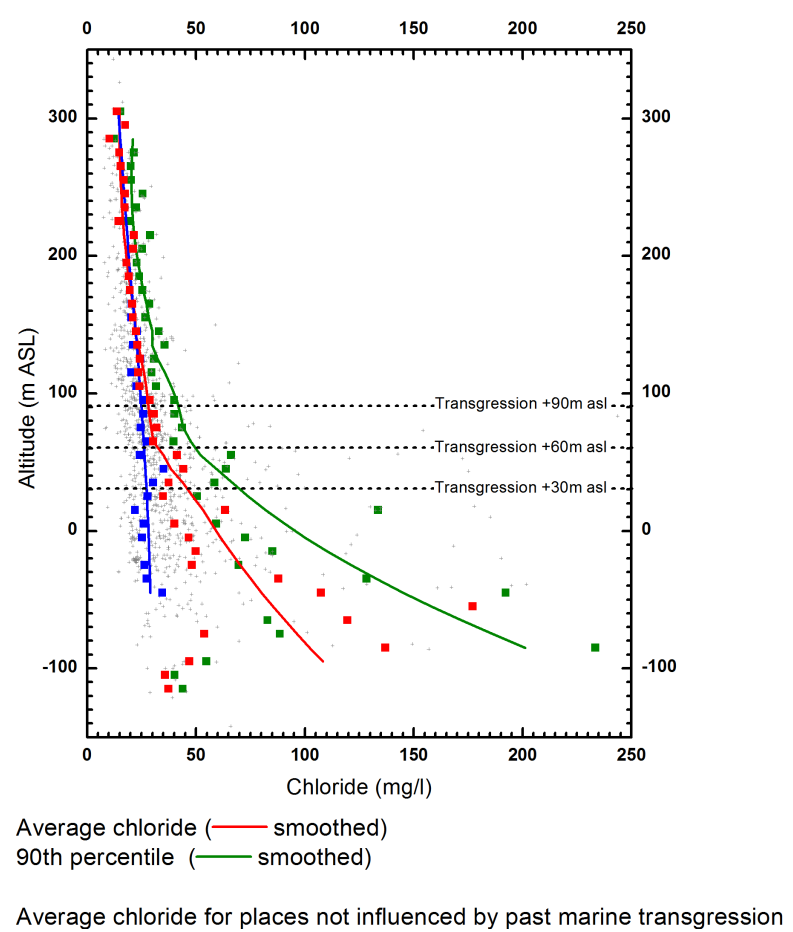

Figure 6. Chloride concentrations versus altitude of well base.

This relationship shown in Fig. 7 can be fitted by a simple exponential function of the general form

$c=c_{\text {in }} \exp -\frac{t_{\mathrm{e}}}{\tau}+c_{\mathrm{o}}$,

where $c$ is the current chloride concentration, $t_{\mathrm{e}}$ the age of the last transgression event, $\tau$ a characteristic timescale, $c_{\mathrm{o}}$ a background concentration, and $c_{\text {in }}$ an additional concentration injected at the time $t$. Equation (1) is the solution of the differential equation

$\frac{\mathrm{d} c}{\mathrm{~d} t}=-\frac{\left(c-c_{\mathrm{o}}\right)}{\tau}+c_{\mathrm{in}} \delta\left(t_{\mathrm{e}}\right)$.

$\delta(t)$, the delta function, simulates quasi-instantaneous injection of chlorides at transgression times. The background chloride concentration $c_{0}$ can be measured in places not influenced by past marine transgression; it is estimated to $21.5 \pm 0.3 \mathrm{mg} \mathrm{L}^{-1}$. The regression fit leads to a time constant $\tau$ of $2.3 \pm 0.1 \mathrm{Myr}$, and an injected concentration of $100 \pm 14 \mathrm{mg} \mathrm{L}^{-1}$. The range errors for $\tau$ and $c_{\text {in }}$ are calculated from the two regression fits generated from the errors in the dating methods used for each characteristic sediment and from the standard deviations of the current chloride concentration of each area. The envelope provided by the two regression fits shows the sensitivity of the parameters according to the standard errors. This residence-time order of magnitude is consistent with the residence time of several million years suggested by Thury et al. (1994) for deep water as well as several studies supporting long residence times required 


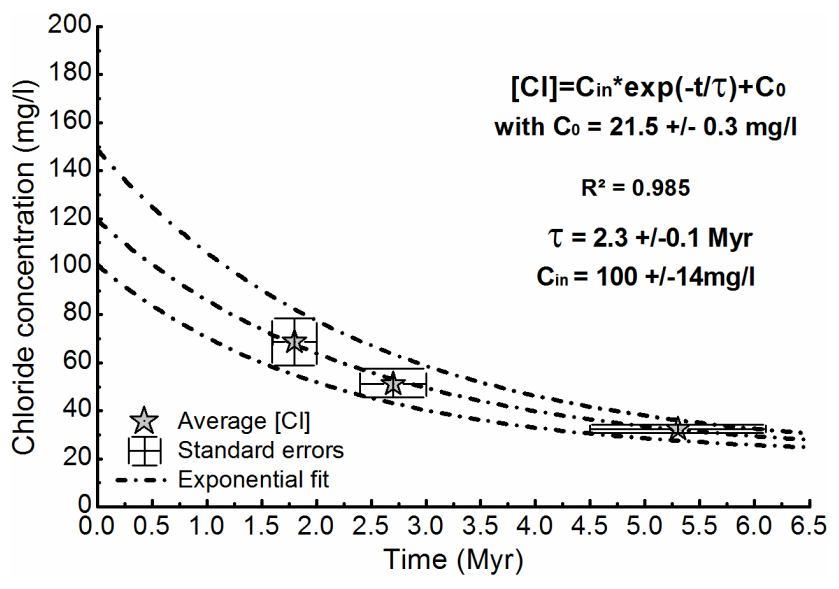

Figure 7. Average chloride concentration for each transgression zone versus the elapsed time since the transgression.

by "fossil" seawater (Stober and Bucher, 1999). It can be noticed that these studies of fluids containing a paleoseawater end-member have chloride concentrations with an order of magnitude similar to those presented here.

\section{Discussion}

\subsection{General trend of increasing salinities with depth}

The main results of this paper present clear evidence of the origin and the age of saline fluids in the continental crust on the scale of the Armorican Massif. We report the vertical distribution of chloride concentration, which presents a concentration increase with depth on the Armorican Massif scale. Such a trend has already been observed in several places throughout the world in continental crusts.

Highly saline brines have been found in various geological environments in the Canadian Shield (Frape et al., 1984; Fritz and Frape, 1982; Gascoyne and Kamineni, 1994), in the crystalline basement of Europe (Black Forest in Germany, Soultz-sous-forêt in France) (Aquilina et al., 1997; Pauwels et al., 1993; Stober and Bucher, 1999), in the Fennoscandian Shield (Fritz, 1997; Nordstrom et al., 1989) and in the England Carnmenellis granite (Edmunds et al., 1985). Saline fluids sampled at these sites report a wide range of chloride concentrations. At the surface, chloride concentration ranges from around 10 to $100 \mathrm{mg} \mathrm{L}^{-1}$; at much greater depths around $500 \mathrm{~m}$, concentration values are between 100 and thousands of $\mathrm{m} \mathrm{L}^{-1}$, and below $1 \mathrm{~km}$ in depth, concentrations range from hundreds to tens of thousands of $\mathrm{mg} \mathrm{L}^{-1}$.

For all these sites, chloride concentrations have been analyzed by intervals of depth where the average chloride concentration is calculated in order to define the concentration gradient until approximately $1 \mathrm{~km}$ in depth (Fig. 8). The Armorican data are also plotted on this graph (Fig. 8). All the studies show a general increase in salinity with depth. In the

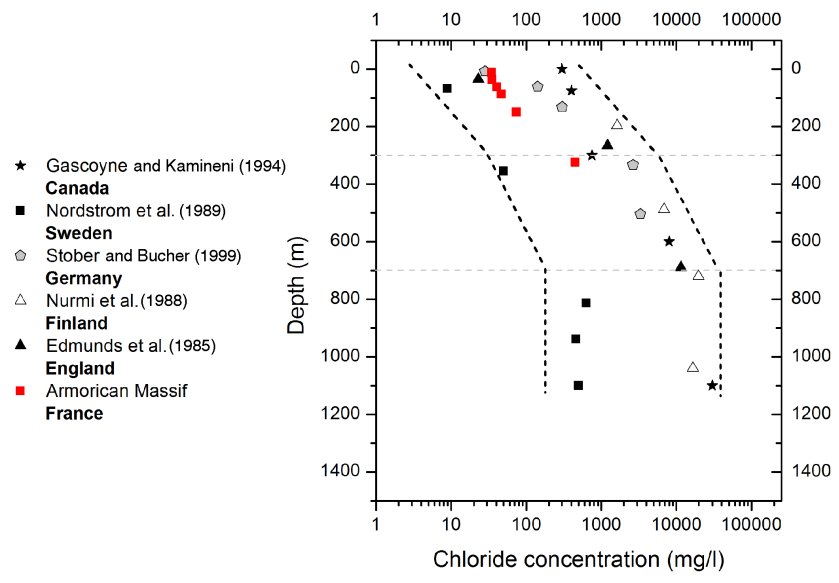

Figure 8. Chloride concentration $\left(\mathrm{mgL}^{-1}\right)$ versus depth (m) recorded in continental basements around the world compared with the data of the current study.

first $300 \mathrm{~m}$, a high gradient of salinity is observed and, between 350 and about $700 \mathrm{~m}$, another gradient is observed. Below this depth, a stabilization seems to be observed, although there are relatively few data (Fig. 8). However, the main difference between all studies relies on chloride concentrations of groundwater samples at shallow depths. In fact, chloride concentrations can vary by 1 order of magnitude, with concentrations around 10 to $100 \mathrm{mg} \mathrm{L}^{-1}$, as for the Armorican basement and the Canadian shields, respectively (Fig. 8).

Previous studies (Aquilina et al., 1997; Edmunds et al., 1985; Frape et al., 1984; Fritz and Frape, 1982; Fritz, 1997; Gascoyne and Kamineni, 1994; Nordstrom et al., 1989; Pauwels et al., 1993; Stober and Bucher, 1999) have been realized in the framework of nuclear repository, geothermal or scientific programs with the aim of investigating the deep continental crust at depths ranging from several hundred meters to several kilometers. In this study, we made a synthesis of a large number of wells in a much shallower part of the crystalline basement ( 41 to $200 \mathrm{~m}$ ). Despite the different purposes, we report similarities, specifically the distribution of chloride with depth, which suggests common hydrogeological mechanisms. The salinity gradient from surface to greater depth and the smoothing of the evolution below a certain depth suggest two hydrodynamic behaviors. Such information can be useful for developing conceptual models of basement aquifer functioning. In addition, in this study, we provide a time frame constraint on these processes in order to contribute to a better understanding.

\subsection{Chloride releasing rate}

Figure 7 shows that the relationship between concentration and transgression age can be fitted by a decreasing exponential function whose parameters give three different characteristics: the background concentration $c_{0}$, which can be in- 
dependently evaluated in places that have not been flooded by marine transgressions, $c_{\text {in }}$ the additional concentration injected in the system during a transgression, and $\tau$ the "dilution" timescale. Note that, even if the choice of the exponential function is rather arbitrary considering the small number of constraints, both $c_{\text {in }}$, the curve extrapolation for an event of age 0 , and $\tau$, the time to achieve a significant decrease, are rather well determined. However, it is also important to note that a situation where three areas have been submerged successively by marine transgressions is exceptional. Even if the three field-base data points make for a weak fit, the contribution provided in the saline fluid residence time is clearly better than all previous studies and consequently constitutes a strong constraint. According to the fitting values, the average chloride concentration likely increased by about $100 \mathrm{mg} \mathrm{L}^{-1}$ after each transgression. This is a rather low value compared to the seawater concentration of $\sim 19 \mathrm{~g} \mathrm{~L}^{-1}$, which indicates that the original seawater has replaced only part of the freshwater initially present. During transgression, mechanism drives the displacement of former fresh groundwater by seawater, but this process enables the saline fluid circulation at great depth in fractured aquifers through the most permeable structures. Nevertheless, all scales of porosity containing former fresh water are not directly influenced. The presence of saline fluid in all scales of porosity requires the diffusion of saline fluid in the long term. Thus, the former fresh water already presented has a great contribution to the injected concentration value and has a strong tendency to decrease the value. Then, the $C_{\text {in }}$ value estimated in our study is related to the entire volume of the aquifer, which tends to reduce the value. And, note that this value corresponds to the increase in the average chloride concentration in the sampling zone that is mostly below $100 \mathrm{~m}$ of the current topography. If there is a systematic increase in chloride concentration with depth, as observed in the upper section, the average will increase as well. A deeper sampling could then give higher $c_{\text {in }}$ values. The fit also indicates that chloride flushing from the aquifers is a process requiring approximately $2.3 \mathrm{Myr}$ to return to initial conditions. The leaching process time constrains the long-term hydrodynamics of Armorican aquifers but incorporates many environmental conditions specific to the Armorican Massif. Indeed, the efficiency of the leaching process is influenced by numerous physical parameters and paleohydrologic conditions. One of the most important parameters is the topographic gradient controlling gravitational flow and consequently fluid migration. However, meteoric fluid migration into deeper parts of aquifer depends on the hydrostratigraphic configuration of the region. The intensity of topography-driven flows is mainly controlled by geographic and climatic conditions. Changes in topographic elevation due to tectonic and erosion processes also impact the behavior of flow systems. In crystalline rock aquifers, such as the Armorican basement, tectonic structures (faults and fractures) play a major role through the formation of preferential pathways. Moreover, sea-level fluctuations can greatly influ- ence topography-driven fluid flow. In the case of an important sea level modification, meteoric fluids may circulate deeper and induce mixing. Thus, the characteristic residence time estimated in our study includes specific physical parameters relating to the Armorican aquifers (geometry of the geological formations, geomorphological features, etc.) and all the changes caused by paleohydrologic conditions since the seawater introduction (tectonic, erosion, sea-level fluctuations, climate changes, etc.). While taking account of the specified points and despite uncertainties in paleocoastlines and the exponential function arbitrarily chosen, the essential point is the clear evidence of past marine transgression during the last million years and thus of leaching processes being active for a similar duration. We use these characteristic times of hydrodynamic processes to constrain the conceptualization of basement aquifer functioning in the two next sections.

\subsection{Conceptualization of Armorican aquifer paleohydrogeology}

The Armorican Massif presents clear evidence of a marine origin of the saline component in the fluids on the massif scale. During marine transgression, seawater was introduced into the basement by density-driven flow. This mechanism induced the displacement of former fresh groundwater by seawater. Then, due to the diffusion process taking place in a million years (according to the time since transgression), the diffusion length scale (a few hundred meters) leads to a perfect mixing between marine waters and freshwaters already present in the whole rock porosity. Third, following transgression, the marine signature contained in the system is flushed out by groundwater circulations fed by meteoric waters. The preservation of a marine signature throughout the Armorican basement and the clear increase with depth support the seawater introduction by gravity-driven flow at depth in the basement followed by a flushing phase with limited downward fresh groundwater circulation loops. The flushing process leads to the displacement of marine waters in the upper part of Armorican aquifers. The limited depth of groundwater circulations is explained by the dense hydrological network, the high sea level and the low topography relief within the Armorican Massif. Moreover, the chloride releasing rate provides a time frame for the flushing process that has been estimated on the order (of magnitude) of a few million years.

Such information can be used to develop conceptual models of the paleo-functioning of Armorican aquifers. The objective of this section is thus to propose conceptual models that may account for the chloride increase with depth on one hand and for the chloride concentration increase fit with time presented above.

The crystalline basement of the Armorican Massif presents aquifers with a high transmissivity associated with fault zones (Roques et al., 2014). Considering the current topography of the Armorican Massif, including three domains of elevations higher than $200 \mathrm{~m}$, the groundwater flow system 
is driven gravitationally, which leads to both local and regional circulation loops (Toth, 1963). Considering the modern situation and constraints provided by the distribution of chloride discussed previously, two main possibilities may explain the distribution of saline fluids in Armorican aquifers.

\subsubsection{First conceptual model: perfectly mixed aquifer}

First, the crystalline rock aquifers are considered as a perfectly mixed reactor where the time constant of millions of years is also the residence time of chlorides in the system. The chloride contained in the system is slowly flushed out by freshwater under the influence of topography-driven groundwater flow (Toth, 1963). This model requires that chlorides are located in a compartment of the groundwater system whose recharge is far lower than the current recharge rate (around $200 \mathrm{~mm} \mathrm{yr}^{-1}$ ) at the top boundary of the system (see Appendix A). This does not necessarily mean that this conceptual model is not consistent with data. On the contrary, it seems consistent with the flow partitioning between local and regional flow systems initially presented (Toth, 1963) and made precise more recently (Cardenas, 2007; Goderniaux et al., 2013). The characteristics of the partitioning between shallow aquifers and deep aquifers have been studied using the topography of Brittany and assuming a constant permeability with depth (Goderniaux et al., 2013). This study shows four interesting results about the partitioning between shallow (short circulations related to first-order basins) and deep (more regional circulations) aquifers: (i) the "deep" compartment can be quite shallow, depending on local topography characteristics; (ii) the residence time of particles is well fitted by an exponential function, which means that the concentration flushing should behave similarly; (iii) the partitioning depends on the total recharge; (iv) the recharge flow in the deep aquifer is $2-5$ times smaller than the total recharge. These recharge values are not small enough to explain the 2.3 Myr residence time observed for chlorides, which could mean either that the first model is inconsistent with data, or that the assumption of Goderniaux et al. (2013) is unrealistic. A permeability decrease with depth may be observed in the continental crust with a likely factor of 100 within the first kilometer (Ingebritsen and Manning, 1999; Saar and Manga, 2004; Stober and Bucher, 2007). Such a decrease could account for a much smaller recharge of the deep groundwater system and thereby a less efficient flushing process. Through modeling is ongoing to test this hypothesis further.

\subsubsection{Second conceptual model: deep reservoir}

In the second case, the presumption is that chlorides could be localized in a deep reservoir, i.e., in the deeper part of the aquifer. Then, chlorides would be leached out from the aquifer system after diffusion from the deep reservoir towards the active part of the crystalline rock aquifers, where leaching is efficient. Calculations for this conceptual model (see Appendix A) lead to a "salt" layer thickness of $40 \mathrm{~m}$ that does not seem unrealistic as regards the chloride evolution with depth observed. However, this conceptual model would predict very high concentrations at depth that are not yet observed in the Armorican basement in the absence of very deep drillings. But, this could be in agreement with highly saline fluids sampled in various geological environments at great depths worldwide (Fig. 8), as in the crystalline basement of the Black Forest, where Stober and Bucher (1999) suggest that the deep saltwater discharges are related to the upwelling of deep water, which may bring up chloride from a deep reservoir. However, it can certainly be affirmed that the salt contained in the deepest part is not solid due to the chloride to bromide relationships, which excludes this possibility.

The next step of this study will be to test these two functioning hypotheses with numerical modeling in order to provide more realistic models. The objective is to provide some constraints on the saline fluid circulation on the regional scale as well as to understand whether the heterogeneity and hydrodynamic conditions may induce a wide range of leaching rates, which could explain the large range of chloride concentrations observed.

\section{Conclusions}

Chloride concentrations in groundwater were investigated in the Armorican basement at shallow depth (from +350 to $-150 \mathrm{~m}$ a.s.l.). The high concentrations observed in some places (from 60 to $1400 \mathrm{mg} \mathrm{L}^{-1}$ ) are shown to originate from marine transgressions. The distributions of high chloride concentrations are in good agreement with both the altitudinal and vertical limits and the succession of the three major transgressions between the Mio-Pliocene and Pleistocene ages. During each of the last transgressions, seawater was introduced by gravity-driven flow at great depth in the basement. This seawater end-member has only partially been flushed by meteoric waters (over 1 to $2 \mathrm{Myr}$ ) between successive marine transgressions and since the last one. Considering the paleocoastlines, three zones have been affected by the transgressions. The average chloride concentration calculated for each area is inversely related to the time elapsed since the last marine transgression. This relationship between concentration and transgression age can be fitted by a decreasing exponential function that indicates that chloride flushing from the aquifers is a process requiring approximately 2 Myr. The fate of chloride is conceptualized using two main models: a dilution or leaching of a deep reservoir. Both models provide information on the history of the saline fluids in fractured aquifers. The first model requires a drastic partitioning between shallow and deep aquifers. In the second model, chlorides are supposed to be released by diffusion from a deep reservoir, leached by fresh groundwater 
flow and brought up to the shallower aquifer. The model supposes a deep reservoir, which has not yet been identified in the Armorican Massif, but which could exist. This study thus provides important constraints on the seawater circulation in hardrock aquifers in a continental-scale area. 


\section{Appendix A}

The objective of this section is to develop simple calculations that aim at figuring out the meaning of the data and fit presented before. We first assume that the average of chloride concentrations measured is related to the average chloride concentration in the aquifer used in the model. Because of the increase in chloride concentration with depth and because of the limited sampling depth, it is unreasonable to pretend that the average of the measurements equals the chloride average concentration in the entire aquifer. Thus, we just guess that the chloride average in the entire aquifer evolves with a similar timescale to the measured averages, which occur for instance if the depth dependency function is similar in different places. Regardless of the model, the general evolution of the chloride concentration is given by a mass balance equation of the type

$$
\frac{\mathrm{d}(V \bar{c})}{\mathrm{d} t}=-Q_{\mathrm{c}}+Q_{\mathrm{in}},
$$

where $V$ is the system volume, $\bar{c}$ the average chloride concentration in the system, $Q_{\mathrm{c}}$ the total flow at the system discharge boundary, and $Q_{\text {in }}$ the total flow at the system recharge boundary. The "system" can be the entire aquifer or any part of it. $Q_{\text {in }}$ represents a potential chloride inflow from the recharge boundary. If we assume a background concentration $c_{0}, Q_{\text {in }}$ can be written as

$Q_{\text {in }}=\iint_{S_{\mathrm{r}}} r(s) \cdot c_{\mathrm{o}} \mathrm{d} s=c_{\mathrm{o}} A_{\mathrm{r}} \bar{r}$,

where $S_{\mathrm{r}}$ is the system recharge boundary, $r(s)$ the recharge at any point $s$ of the boundary, $A_{\mathrm{r}}$ the recharge boundary surface, and $\bar{r}$ the average recharge flow.

We then define two end-member models that may explain the chloride evolution in basement aquifers.

\section{The perfectly mixed aquifer}

In the first model, the chloride contained in the deeper part of the aquifer is slowly flushed out from the system along the discharge at a rate $Q_{\mathrm{c}}$ such as

$Q_{\mathrm{c}}=\iint_{S_{\mathrm{d}}} q(s) \cdot c(s) \cdot \mathrm{d} s$,

where $S_{\mathrm{d}}$ is the system discharge boundary, $q(s)$ the flow discharge at any point $s$ of the boundary, and $c(s)$ the chloride concentration. In a perfectly mixed reactor, the total concentration at the boundary is equal to the concentrations' average. Even if this approximation is certainly unlikely in highly heterogeneous aquifers, we assume that the $Q_{\mathrm{c}}$ integral can be estimated from the averages of concentrations and discharge $Q_{\mathrm{c}}$ defined as
$Q_{\mathrm{c}}=O A_{\mathrm{d}} \overline{q c}$

where $\bar{q}$ and $\bar{c}$ are the discharge and concentration averages, respectively, and $A_{\mathrm{d}}$ is the total surface of the system discharge boundary. $O(1)$ is a constant equal to 1 in the perfectly mixed approximation, and whose order of magnitude is about 1 if the approximation is not rigorously exact. The water mass balance requires that the total discharge equals the total recharge: $A_{\mathrm{d}} \bar{q}=A_{\mathrm{r}} \bar{r}$. If we assume that the aquifer system is a rectangular box fed from above with a recharge $r$, using a thickness $h=\frac{V}{A_{\mathrm{r}}}$, Eq. (3) is written as a first-order kinetic equation

$\frac{\mathrm{d} \bar{c}}{\mathrm{~d} t}=\frac{\left(c_{\mathrm{o}}-O(1) \cdot \bar{c}\right)}{\tau}$,

with the time constant $\tau$ equal to $\frac{h}{r}$.

If we consider that $r$ is on the same order as it is now in Brittany (about $200 \mathrm{~mm} \mathrm{yr}^{-1}$ ), given the time constant $\tau$ of $2.3 \mathrm{Myr}$, we predict an unrealistic aquifer depth $h$ of about $500 \mathrm{~km}$. Although the actual depth is not known, it is likely less than a few $\mathrm{km}$ and more likely about $1 \mathrm{~km}$. This means that the dilution model is valid only if the recharge is at least 2 to 3 orders of magnitude fewer than the current rainfall.

\section{The deep reservoir diffusion model}

In the second model, we assume that chlorides are leached out from the aquifer system by diffusion from a deep layer of thickness $h^{\prime}$ without any advection. $Q_{\mathrm{c}}$ is a bit different from Eq. (7) because diffusion occurs i) on all the system boundaries, and ii) at a rate equal to $q(s)=D \frac{\partial c(s)}{\partial n}$, where $n$ is the direction $q(s)$. We assume that the concentration gradient is established in a length scale on the order of the smallest aquifer dimension $h^{\prime}$, which is a reasonable assumption if the aquifer thickness is small compared to its horizontal extent $Q_{\mathrm{c}}$ defined as

$Q_{\mathrm{c}}=O^{\prime} A D \frac{\left(\bar{c}-c_{\mathrm{o}}\right)}{h^{\prime}}$,

with $O$ an order-of-magnitude constant similar to $O$. The influx $Q_{\text {in }}$ is now nil and the general equation is written as

$\frac{\mathrm{d} \bar{c}}{\mathrm{~d} t}=\frac{\left(c_{\mathrm{o}}-\bar{c}\right)}{\tau^{\prime}}$,

with $\tau^{\prime}=O^{\prime-1} \frac{h^{\prime 2}}{D}$.

The molecular diffusion $D_{\mathrm{m}}$ of chloride in water is on the order of $2 \times 10^{-9} \mathrm{~m}^{2} \mathrm{~s}^{-1}$ ( $\mathrm{Li}$ and Gregory, 1974; Wang et al., 1953). Considering a porosity of $1 \%$, the diffusion $D$ of chloride is on the order of $2 \times 10^{-11} \mathrm{~m}^{2} \mathrm{~s}^{-1}$. A time constant of $2.3 \mathrm{Myr}$ is thus consistent with a salt layer thickness of about $40 \mathrm{~m}$. 
Acknowledgements. We thank the BRGM for the access to the national databases for groundwater resources and drillings. This research was supported by the EU-funded projects Interreg IVa CLIMAWAT and cluster 3C. We are grateful for technical reviews, two anonymus reviewers and the associate editor.

Edited by: .G. Fogg

\section{References}

Aquilina, L. and Dreuzy, J.-R. De: Relationship of present saline fluid with paleomigration of basinal brines at the basement/sediment interface (Southeast basin - France), Appl. Geochem., 26, 1933-1945, doi:10.1016/j.apgeochem.2011.06.022, 2011.

Aquilina, L., Pauwels, H., Genter, A., and Fouillac, C.: Water-rock interaction processes in the Triassic sandstone and the granitic basement of the Rhine Graben: Geochemical investigation of a geothermal reservoir, Geochim. Cosmochim. Acta, 61, 42814295, doi:10.1016/S0016-7037(97)00243-3, 1997.

Aquilina, L., Armandine Les Landes, A., Ayraud-Vergnaud, V., Labasque, T., Roques, C., Davy, P., Pauwels, H. and PeteletGiraud, E.: Evidence for a Saline Component at Shallow Depth in the Crystalline Armorican Basement (W France), Proced. Earth Planet. Sci., 7, 19-22, doi:10.1016/j.proeps.2013.03.157, 2013.

Aquilina, L., Vergnaud-Ayraud, V., Armandine Les Landes, A., Pauwels, H., Davy, P., Petelet-Giraud, E., Labasque, T., Roques, C., Bour, O., Ben Maamar, S., Kaskha, M., Le Gal La Salle, C., Barbecot, F., and Team, A.: Impact of climate changes during the last 5 million years on groundwaters in basement aquifers, Scientific reports, submitted, 2015.

Ayraud, V., Aquilina, L., Labasque, T., Pauwels, H., Molenat, J., Pierson-Wickmann, A.-C., Durand, V., Bour, O., Tarits, C., Le Corre, P., Fourre, E., Merot, P., and Davy, P.: Compartmentalization of physical and chemical properties in hard-rock aquifers deduced from chemical and groundwater age analyses, Appl. Geochem., 23, 2686-2707, doi:10.1016/j.apgeochem.2008.06.001, 2008.

Banks, D., Odling, N., Skarphagen, H., and Rohr-Torp, E.: Permeability and stress in crystalline rocks, Terra Nov., 8, 223-235, 1996.

Beaucaire, C., Gassama, N., and Tresonne, N.: Saline groundwaters in the hercynian granites (Chardon Mine, France): geochemical evidence for the salinity origin, Appl. Geochem., 14, 67-84, doi:10.1016/S0883-2927(98)00034-1, 1999.

Bonnet, S., Guillocheau, F., and Brun, J. P.: Relative uplift measured using river incisions: the case of the armorican basement (France), Surf. Geosci., 327, 245-251, 1998.

Bonnet, S., Guillocheau, F., and Brun, J.: Large-scale relief development related to Quaternary tectonic uplift of a ProterozoicPaleozoic basement?, J. Geophys. Res., 105, 19273-19288, 2000.

Bottomley, D. J., Gregoire, D. C., and Ravens, K. G.: Saline groundwaters and brines in the Canadian Shield: Geochemical for a residual evaporite brine component and isotopic evidence, Geochim. Cosmochim. Acta, 58, 1483-1498, 1994.

Bottomley, D. J., Katz, A., Chan, L. H., Starinsky, A., Douglas, M., Clark, I. D., and Raven, K. G.: The origin and evolution of Canadian Shield brines: evaporation or freezing of seawater? New lithium isotope and geochemical evidence from the Slave craton, Chem. Geol., 155, 295-320, doi:10.1016/S00092541(98)00166-1, 1999.

Brault, N.: Ressources du sous-sol et environnement en Bretagne, Génèse, géométrie et propriétés de différents types d'aquifères, University of Rennes 1, Rennes, 2002.

Brault, N., Bourquin, S., Guillocheau, F., Dabard, M.-P., Bonnet, S., Courville, P., Estéoule-Choux, J. and Stepanoff, F.: MioPliocene to Pleistocene paleotopographic evolution of Brittany (France) from a sequence stratigraphic analysis: relative influence of tectonics and climate, Sediment. Geol., 163, 175-210, doi:10.1016/S0037-0738(03)00193-3, 2004.

Bucher, K. and Stober, I.: Fluids in the upper continental crust, Geofluids, 10, 241-253, doi:10.1111/j.1468-8123.2010.00279.x, 2010.

Cardenas, M. B.: Potential contribution of topography-driven regional groundwater flow to fractal stream chemistry: Residence time distribution analysis of Tóth flow, Geophys. Res. Lett., 34, L05403, doi:10.1029/2006GL029126, 2007.

Carpenter, A. B.: Origin And Chemical Evolution Of Brines In Sedimentary Basins, in: SPE Annual Fall Technical Conference and Exhibition, 1-3 October 1978.

Casanova, J., Negrel, P., Kloppmann, W., and Aranyossy, J. F.: Origin of deep saline groundwaters in the Vienne granitic rocks (France): constraints inferred from boron and strontium isotopes, Geofluids, 1, 91-101, doi:10.1046/j.1468-8123.2001.00009.x, 2001.

Chantraine, J., Egal, E., Thieblemont, D., Le Goff, E., Guerrot, C., and Ballevre, M.: The Cadomian active margin (North Armorican Massif, France): a segment of the North Atlantic Panafrican belt, Tectonophysics, 331, 1-18, 2001.

Clauser, C.: Permeability of crystalline rocks, Eos Trans. Am. Geophys. Union, 73, 233-238, 1992.

Dewandel, B., Lachassagne, P., and Wyns, R.: A generalized 3$\mathrm{D}$ geological and hydrogeological conceptual model of granite aquifers controlled by single or multiphase weathering, J. Hydrol., 330, 260-284, doi:10.1016/j.jhydrol.2006.03.026, 2006.

Dorn, C., Linde, N., Doetsch, J., Le Borgne, T., and Bour, O.: Fracture imaging within a granitic rock aquifer using multiple-offset single-hole and cross-hole GPR reflection data, J. Appl. Geophys., 78, 123-132, doi:10.1016/j.jappgeo.2011.01.010, 2012.

Douglas, M., Clark, I. D., Raven, K., and Bottomley, D.: Groundwater mixing dynamics at a Canadian Shield mine, J. Hydrol., 235, 88-103, doi:10.1016/S0022-1694(00)00265-1, 2000.

Dugué, O.: Le Massif Armoricain dans l'evolution Mésozoique et Cénozoique du Nord-Ouest de l'Europe, Contrôles tectonique, eustatique et climatique d'un bassin intracratonique (Normandie, Mer de la Manche, France), University of Caen, Caen, 2007.

Edmunds, W., Kay, R. L. F., and McCartney, R.: Origin of saline groundwaters in the Carnmenellis granite (Cornwall, England): Natural processes and reaction during hot dry rock reservoir circulation, Chem. Geol., 49, 287-301, 1985.

Edmunds, W. and Savage, D.: Geochemical Characteristics of Groundwater in Granites and Related Crystalline Rocks, in: Applied Groundwater Hydrology, edited by: Downing, R. A. and Wilkinson, W. B., Clarendon Press, Oxford, UK, 1991.

Frape, S., Fritz, P., and Blackmer, A.: Saline groundwater discharges from crystalline rocks near Thunder Bay, Ontario, 
Canada, Balanc. Freshw. Syst. available at: http://iahs.info/ redbooks/a150/150034.pdf (last access: 15 March 2013), 1984.

Frape, S. K., Blyth, A., Blomqvist, R., McNutt, R. H., and Gascoyne, M.: Deep Fluids in the Continents: II. Crystalline rocks, edited by: Drever, J. I., Holland, H. D., and Turekian, K. K. Treatise on Geochemistry, Vol. 5, Surface and Groundwater,Weathering, and Soils, Elsevier-Pergamon, Oxford, p. 560, 2003.

Freeman, J. T.: The use of bromide and chloride mass ratios to differentiate salt-dissolution and formation brines in shallow groundwaters of the Western Canadian Sedimentary Basin, Hydrogeol. J., 15, 1377-1385, 2007.

Fritz, P.: Saline groundwater and brines in crystalline rocks: the contributions of John Andrews and Jean-Charles Fontes to the solution of a hydrogeological and geochemical problem, Appl. Geochemistry, 12, 851-856, doi:10.1016/S0883-2927(97)00074-7, 1997.

Fritz, P. and Frape, S. K.: Saline groundwaters in the Canadian Shield - A first overview, Chem. Geol., 36, 179-190, 1982.

Gascoyne, M. and Kamineni, D. C.: The Hydrogeochemistry Of Fractured Plutonic Rocks In The Canadian Shield, Hydrogeol. J., 2, 43-49, doi:10.1007/s100400050044, 1994.

Goderniaux, P., Davy, P., Bresciani, E., de Dreuzy, J.-R., and Le Borgne, T.: Partitioning a regional groundwater flow system into shallow local and deep regional flow compartments, Water Resour. Res., 49, 2274-2286, doi:10.1002/wrcr.20186, 2013.

Greene, S., Battye, N., Clark, I., Kotzer, T., and Bottomley, D.: Canadian Shield brine from the Con Mine, Yellowknife, NT, Canada: Noble gas evidence for an evaporated Palaeozoic seawater origin mixed with glacial meltwater and Holocene recharge, Geochim. Cosmochim. Acta, 72, 40084019, doi:10.1016/j.gca.2008.05.058, 2008.

Gros, Y. and Limasset, O.: Déformation récente dans les socles cristallins, Exemple du Massif Armoricain, BRGM, Orléans-laSource, 1984.

Guillocheau, F., Brault, N., Thomas, E., Barbarand, J., Bonnet, S., Bourquin, S., Estéoule-Choux, J., Guennoc, P., Menier, D., Néraudeau, D., Proust, J.-N., and Wyns, R.: Histoire géologique du Massif Armoricain depuis 140 MA (CrétacéActuel)-Geological history of the Armorican Massif since 140 My (Cretaceous-Present Day), Bull. Inf., 40, 13-28, 2003.

Gumiaux, C., Gapais, D., Brun, J. P., Chantraine, J., and Ruffet, G.: Tectonic history of the Hercynian Armorican Shear belt (Brittany, France), Geodin. Acta, 17, 289-307, 2004.

Hardenbol, J. A. N., Thierry, J., Farley, M. B., Cnrs, U. R. A., and Vail, P. R.: Mesozoic and Cenozoic sequence chronostratigraphic fremework of European basins, The chronostratigraphic charts presented in this paper are the result of an initiative by Peter Vail and Thierry Jacquin in 1990 to analyze and document depositional sequence, SEPM Spec. Publ., 60, 3-13, 1998.

Ingebritsen, S. and Manning, C. E.: Geological implications of a permeability-depth curve for the continental crust, Geology, 27, 1107-1110, 1999.

Jost, A.: Caractérisation des forçages climatiques et géomorphologiques des cind derniers millions d'années et modélisation de leurs conséquences sur un système aquifère complexe: le bassin de Paris, PhD, University of Pierre and Marie Curie, Paris, 344 pp., 2005.
Kelly, V. R., Lovett, G. M., Weathers, K. C., Findlay, S. E. G., Strayer, D. L., Burns, D. J., and Likens, G. E.: Long-Term Sodium Chloride Retention in a Rural Watershed: Legacy Effects of Road Salt on Streamwater Concentration, Environ. Sci. Technol., 42, 410-415, doi:10.1021/es0713911, 2008.

Lague, D., Davy, P., and Crave, A.: Estimating Uplift Rate and Erodibility from the Area-Slope Examples from Brittany (France) and Numerical Modelling Relationship, Phys. Chem. Earth, 25, 543-548, 2000.

Larsson, I.: Les eaux souterraines des roches dures du socle: Projet 8.6 du Programme Hydrologique International, Report, Paris, edited by: UNESCO, collection Etudes et rapports d'hydrologie, 33, 282 pp., 1987.

Le Borgne, T., Bour, O., de Dreuzy, J. R., Davy, P., and Touchard, F.: Equivalent mean flow models for fractured aquifers: Insights from a pumping tests scaling interpretation, Water Resour. Res., 40, W03512, doi:10.1029/2003WR002436, 2004.

Le Borgne, T., Bour, O., Paillet, F. L., and Caudal, J.-P.: Assessment of preferential flow path connectivity and hydraulic properties at single-borehole and cross-borehole scales in a fractured aquifer, J. Hydrol., 328, 347-359, doi:10.1016/j.jhydrol.2005.12.029, 2006.

Le Corre, C., Auvray, B., Ballèvre, M., and Robardet, M.: Le Massif Armoricain, Sci. Geol. Bull., 44, 31-103, 1991.

Lefebvre, D., Antoine, P., Auffret, J. P., Lautridou, J. P., and Lécolle, F.: Réponses de la Seine et de la Somme aux événements climatiques, eustatiques et tectoniques du Pléistocène moyen et récent?: rythmes et taux d'érosion - The responses of the river Seine and of the river Somme to the climatic, eustatic and tectonic controls, Quaternaire, 5, 165-172, doi:10.3406/quate.1994.2028, 1994.

Lenôtre, N., Thierry, P., Blanchin, R., and Brochard, G.: Current vertical movement demonstrated by comparative levelling in Brittany (northwestern France), Tectonophysics, 301, 333-344, 1999.

Leray, S., de Dreuzy, J.-R., Bour, O., and Bresciani, E.: Numerical modeling of the productivity of vertical to shallowly dipping fractured zones in crystalline rocks, J. Hydrol., 481, 64-75, doi:10.1016/j.jhydrol.2012.12.014, 2013.

Li, Y.-H. and Gregory, S.: Diffusion of ions in sea water and in deep-sea sediments, Geochim. Cosmochim. Acta, 38, 703-714, 1974.

Louvat, D., Michelot, J.-L., and Aranyossy, J. F.: Origin and residence time of salinity in the Aspo groundwater system, Appl. Geochemistry, 14, 917-925, 1999.

Martin, C., Aquilina, L., Gascuel-Odoux, C., Molénat, J., Faucheux, M., and Ruiz, L.: Seasonal and interannual variations of nitrate and chloride in stream waters related to spatial and temporal patterns of groundwater concentrations in agricultural catchments, Hydrol. Process., 18, 1237-1254, 2004.

Mercier, D., Brulhet, J., Beaudoin, B., Cahuzac, B., Laurent, M., Lauriat-Rage, A., Margerel, J. P., Moguedet, G., Moritz, R., Sierra, P., Thiry, M., Turpin, L., Van Vliet-Lanoë, B., and Vauthier, S.: Le Redonien de l'Ouest de la France?: enregistrement des événements (climatiques, eustatiques) messiniens et pliocènes sur la façade atlantique, 1res journées GFEN-APF, Rennes, 6-7 December, 12-13, 2000.

Morzadec-Kerfourn, M.-T.: La limite Pliocene-Pleistocene en Bretagne, Boreas, 6, 275-283, 1977. 
Morzadec-Kerfourn, M. T.: Datation pollinique et conditions de sédimentation de l'argile plio-pléistocène de Lanrinou en Landerneau, Bull. l'Association française pour l'étude du Quat., 19, 179-184, 1982.

Morzadec-Kerfourn, M. T.: Dinoflagellate cysts and the paleoenvironment of late Pliocene early-Pleistocene deposits of Brittany, Quaternary Sci. Rev., 16, 883-898, 1997.

Mullaney, J. R., Lorenz, D. L., and Arntson, A. D.: Chloride in Groundwater and Surface Water in Areas Underlain by the Glacial Aquifer System, Northern United States Scientific Investigations Report 2009-5086, Northern United States Scientific Investigations, Report 2009-5086, USGS, New York, 2009.

Müller, B., Zoback, M. L., Fuchs, K., Mastin, L., Gregersen, S., Pavoni, N., Stephansson, O., and Ljunggren, C.: Regional Patterns of Tectonic Stress in Europe, J. Geophys. Res., 97, 1178311803, 1992.

Négrel, P. and Casanova, J.: Comparison of the $\mathrm{Sr}$ isotopic signatures in brines of the Canadian and Fennoscandian shields, Appl. Geochemistry, 20, 749-766, doi:10.1016/j.apgeochem.2004.11.010, 2005.

Néraudeau, D., Mercier, D., Van Vliet-Lanoë, B., and Lauriat-Rage, A.: Les faluns redoniens stratotypiques, enregistrement partiel du Messinien atlantique, 1res journées GFEN-APF, 2002.

Néraudeau, D., Barbe, S., Mercier, D., and Roman, J.: Signatures paléoclimatiques des échinides du Néogène final atlantique à faciès redonien, Ann. Paléontologie, 89, 153-170, doi:10.1016/S0753-3969(03)00023-5, 2003.

Néraudeau, D., Dudicourt, J.-C., Boutin, F., Ceulemans, L., and Nicolleau, P.: Les Spatangus du Miocène et du Pliocène de l'Ouest de la France, Ann. Paléontologie, 96, 159-170, doi:10.1016/j.annpal.2011.05.001, 2010.

Nicolas, M., Santoire, J. P., and Delpech, P. Y.: Intraplate seismicity: new seismotectonic data in Western Europe, Tectonophysics, 179, 27-53, doi:10.1016/0040-1951(90)90354-B, 1990.

Nordstrom, D. K., Olsson, T., Carlsson, L., Fritz, P., Survey, U. S. G., Road, M., and Park, M.: Introduction to the hydrogeochemical investigations within the International Stripa Project, Geochim. Cosmochim. Acta, 53, 1717-1726, 1989.

Panno, S. V., Hackley, K. C., Hwang, H. H., Greenberg, S. E., Krapac, I. G., Landsberger, S., and O'Kelly, D. J.: Characterization and identification of $\mathrm{Na}-\mathrm{Cl}$ sources in ground water., Ground Water, 44, 176-87, doi:10.1111/j.1745-6584.2005.00127.x, 2006.

Pauwels, H., Fouillac, C., and Fouillac, A.: Chemistry and isotopes of deep geothermal saline fluids in the Upper Rhine Graben: Origin of compounds and water-rock interactions, Geochim. Cosmochim. Acta, 57, 2737-2749, 1993.

Pauwels, H., Ayraud-Vergnaud, V., Aquilina, L., and Molénat, J.: The fate of nitrogen and sulfur in hard-rock aquifers as shown by sulfate-isotope tracing, Appl. Geochem., 25, 105-115, doi:10.1016/j.apgeochem.2009.11.001, 2010.

Pauwels, H., Aquilina, L., Negrel, P., Bour, O., Perrin, J., and Ahmed, S.: Groundwater Salinization in Hard-Rock Aquifers: Impact of Pumping and Vertical Transfers, Proced. Earth Planet. Sci., 7, 660-664, doi:10.1016/j.proeps.2013.03.189, 2013.

Perera, N., Gharabaghi, B., and Howard, K.: Groundwater chloride response in the Highland Creek watershed due to road salt application: A re-assessment after 20 years, J. Hydrol., 479, 159-168, doi:10.1016/j.jhydrol.2012.11.057, 2013.
Roques, C.: Hydrogeologie des zones de faille du socle cristallin: implications en terme de ressources en eau pour le Massif Armoricain, PhD, University of Rennes 1, Rennes, 266 pp., 2013.

Roques, C., Bour, O., Aquilina, L., Dewandel, B., Leray, S., Schroetter, J., Longuevergne, L., Le Borgne, T., Hochreutener, R., Labasque, T., Lavenant, N., Vergnaud-Ayraud, V., and Mougin, B.: Hydrological behavior of a deep sub-vertical fault in crystalline basement and relationships with surrounding reservoirs, J. Hydrol., 509, 42-54, 2014.

Saar, M. O. and Manga, M.: Depth dependence of permeability in the Oregon Cascades inferred from hydrogeologic, thermal, seismic, and magmatic modeling constraints, J. Geophys. Res., 109, B04204, doi:10.1029/2003JB002855, 2004.

Starinsky, A. and Katz, A.: The formation of natural cryogenic brines, Geochim. Cosmochim. Acta, 67, 1475-1484, doi:10.1016/S0016-7037(02)01295-4, 2003.

Stober, I. and Bucher, K.: Deep groundwater in the crystalline basement of the Black Forest region, Appl. Geochem., 14, 237-254, doi:10.1016/S0883-2927(98)00045-6, 1999.

Stober, I. and Bucher, K.: Hydraulic properties of the crystalline basement, Hydrogeol. J., 15, 213-224, doi:10.1007/s10040-0060094-4, 2007.

Stober, I., Richter, A., Brost, E., and Bucher, K.: The Ohlsbach Plume - Discharge of deep saline water from the crystalline basement of the Black Forest, Germany, Hydrogeol. J., 7, 273-283, doi:10.1007/s100400050201, 2002.

Thomas, E.: Evolution Cenozoique d'un domaine de socle: Le Massif Armoricain, PhD Thesis, University of Grenoble, Grenoble, 250 pp., 1999.

Thury, M., Gautschi, A., Mazurek, M., Müller, W. H., Naef, H., Pearson, F. J., Vomvoris, S., and Wilson, W.: Geology and Hydrogeology of the Crystalline Basement of Northern Switzerland. Synthesis of Regional Investigations 1981-1993 within the Nagra Radioactive Waste Disposal Programme, Technical Report, Nagra, 1994.

Toth, J.: A theoretical analysis of groundwater flow in small drainage basins, J. Geophys. Res., 68, 4795-4812, 1963.

Touchard, F.: Caractérisation hydrogéologique d'un aquifère de socle fracturé: site de Ploemeur (Morbihan), 1999.

Van Vliet-Lanoe, B., Laurent, M., Hallégouët, B., Margerel Jeanpierre, Chauvel, J., Michel, Y., Moguedet, G., Trautman, F., and Vauthier, S.: Le Mio-Plioche du Massif armoricain. Données nouvelles - The Mio-Pliocene of the Armorican Massive. New data, Surf. Geosci., 326, 333-340, 1998.

Wang, J., Robinson, C., and Edelman, I.: Self diffusion and structure of liquid water with ${ }^{2} \mathrm{H},{ }^{3} \mathrm{H}$ and ${ }^{18} \mathrm{O}$ as tracers, J. Am. Chem. Soc., 75, 466-470, 1953.

Wyns, R., Baltassat, J., Lachassagne, P., and Legchenko, A.: Application of proton magnetic resonance soundings to groundwater reserve mapping in weathered basement rocks, Bull. Société Géologique Fr., 21-34, 2004.

Ziegler, P. A.: Geological atlas of Western and Central Europe, Shell International Petroleum Mij. B.B, 2nd Edn., Geol. Soc. Publ. House, Bath, 239 pp., 1990. 